\title{
Arsenic Toxicity in Male Reproduction and Development
}

\author{
Yoon-Jae Kim and ${ }^{\dagger}$ Jong-Min Kim \\ Dept. of Anatomy and Cell Biology, College of Medicine, Dong-A University, Busan 602-714, Korea
}

\begin{abstract}
Arsenic is a toxic metalloid that exists ubiquitously in the environment, and affects global health problems due to its carcinogenicity. In most populations, the main source of arsenic exposure is the drinking water. In drinking water, chronic exposure to arsenic is associated with increased risks of various cancers including those of skin, lung, bladder, and liver, as well as numerous other non-cancer diseases including gastrointestinal and cardiovascular diseases, diabetes, and neurologic and cognitive problems. Recent emerging evidences suggest that arsenic exposure affects the reproductive and developmental toxicity. Prenatal exposure to inorganic arsenic causes adverse pregnancy outcomes and children's health problems. Some epidemiological studies have reported that arsenic exposure induces premature delivery, spontaneous abortion, and stillbirth. In animal studies, inorganic arsenic also causes fetal malformation, growth retardation, and fetal death. These toxic effects depend on dose, route and gestation periods of arsenic exposure. In males, inorganic arsenic causes reproductive dysfunctions including reductions of the testis weights, accessory sex organs weights, and epididymal sperm counts. In addition, inorganic arsenic exposure also induces alterations of spermatogenesis, reductions of testosterone and gonadotrophins, and disruptions of steroidogenesis. However, the reproductive and developmental problems following arsenic exposure are poorly understood, and the molecular mechanism of arsenic-induced reproductive toxicity remains unclear. Thus, we further investigated several possible mechanisms underlying arsenic-induced reproductive toxicity.
\end{abstract}

Key words : Arsenic, Reproduction, Development, Steroidogenesis, Male

\section{INTRODUCTION}

Arsenic is a naturally occurring element that exists ubiquitously in the environment in both organic and inorganic forms combined with other elements such as oxygen, chlorine, and sulfur, as well as carbon and hydrogen (Cullen and Reimer, 1989; WHO, 2000; IARC, 2004). It is classified chemically as a metalloid, having properties intermediate between a metal and a nonmetal; however, it is frequently referred to as a metal (IARC, 1980). Elemental arsenic is the $20^{\text {th }}$ most common in the earth's crust, and is emitted to the environment as a result of volcanic and industrial activities. Mining, smelting of non-ferrous metals and burning of fossil fuels are the major anthropogenic sources of arsenic contamination of air, water, and soil. Arsenic and arsenic compounds are used in pharmaceuticals, wood preservatives, agricultural chemicals (e.g. pesticides, insecticides, and herbicides), and applications in the mining, metallurgical, glass-making, and semiconductor industries (Mandal, 2002). Especially, the historical usage of arsenic-containing pesticides and wood preservatives led to contamination of the agricultural land and groundwater (WHO, 2001). Human

\footnotetext{
Manuscript received October 15, 2015, Received in revised form October 23, 2015, Accepted November 5, 2015

${ }^{\dagger}$ Corresponding Author : Jong-Min Kim, Department of Anatomy and Cell Biology, College of Medicine, Dong-A University, Busan 602-714, Korea. Tel. : +82-51-240-2792, Fax :+82-51-245-3872, E-mail : jmkim7@dau.ac.kr

This is an Open Access article distributed under the terms of the Creative Commons Attribution Non-Commercial License (http:// creativecommons.org/licenses/by-nc/3.0) which permits unrestricted non-commercial use, distribution, and reproduction in any medium, provided the original work is properly cited.
} 
exposure to arsenic has become a major global health problem because the worldwide contaminations and adverse health effects. In most populations, the main source of arsenic exposure is the drinking water (NRC, 1999, 2001; Smith et al., 2002; Watanabe et al., 2003). In drinking water, the current maximum contamination levels of arsenic were lowered from $50 \mu \mathrm{g} / \mathrm{L}$ to $10 \mu \mathrm{g} / \mathrm{L}$ by USEPA and WHO (IARC, 2004). Arsenic in drinking water is mainly inorganic arsenic and more harmful than in food such as grains and vegetables (Akter et al., 2005). Moreover, inorganic arsenic is more toxic than organic arsenic and can exist in two major oxidation states: a trivalent form, arsenite $\left(\mathrm{As}^{3+}\right)$, and a pentavalent form, arsenate $\left(\mathrm{As}^{5+}\right)$. Biologically, arsenite is $2 \sim 10$-fold more active and toxic than arsenate (Kosentt, 1994). Of the inorganic arsenic compounds, arsenic trioxide $\left(\mathrm{As}_{2} \mathrm{O}_{3}\right)$, sodium arsenite $\left(\mathrm{NaAsO}_{2}\right)$ and arsenic trichloride $\left(\mathrm{AsCl}_{3}\right)$ are the most common trivalent compounds, and arsenic pentoxide $\left(\mathrm{As}_{2} \mathrm{O}_{5}\right)$, arsenic acid $\left(\mathrm{AsH}_{3} \mathrm{O}_{4}\right)$ and arsenates [e.g. sodium arsenate $\left(\mathrm{Na}_{2} \mathrm{HAsO}_{4}\right)$, lead arsenate $\left(\mathrm{PbHAsO}_{4}\right)$ and calcium arsenate $\left.\left(\mathrm{As}_{2} \mathrm{Ca}_{3} \mathrm{O}_{8}\right)\right]$ are most common pentavalent compounds.

The toxic effects of arsenic that are of most concern to humans are those that occur from chronic low-level exposure. Epidemiological studies have indicated that chronic exposure to arsenic is associated with increased risks of various cancers, including those of the skin, lung, bladder, kidney, and liver, as well as numerous other non-cancer illnesses including vascular and cardiovascular disease, diabetes, reproductive and developmental problems, and neurologic and cognitive problems (Abernathy et al., 2003' NRC 1999, 2001; Wasserman et al., 2004; Watanabe et al., 2003). Conversely, arsenic has been considered as an effective chemotherapeutic agent in the treatment of certain human cancers (Douer \& Tallman, 2005). Among arsenic compounds, arsenic trioxide $\left(\mathrm{As}_{2} \mathrm{O}_{3}\right)$ has successfully been employed in the treatment of acute promyelocytic leukemia (APL) (Soignet et al., 1998). It has also been shown that $\mathrm{As}_{2} \mathrm{O}_{3}$ efficiently induces apoptosis in malignant APL cells in vitro (Hu et al., 1999). These observations has been confirmed that $\mathrm{As}_{2} \mathrm{O}_{3}$ can induce apoptosis in other leukemia cells and solid tumor cells, including gastric cancer cells, neuroblastoma cells, and prostate and ovarian carcinomas (Zhang el al., 1999; Uslu et al., 2000). However, arsenic is commonly regarded as a potent carcinogen that can induce the formation of various types of solid tumors (Smith et al., 1992; Liu \& Waalkes, 2008). Our previously study demonstrated that $\mathrm{As}_{2} \mathrm{O}_{3}$ effectively provokes cytotoxicity and apoptotic cell death in mouse testicular Sertoli cells in vitro (Kim et al., 2011). These investigations indicates that the male reproductive toxicity of arsenic may be directly associated with damage of testicular cells.

In addition, various experimental models have been developed to understand how arsenic exposure causes these diverse disease outcomes. However, the reproductive and developmental toxicity of arsenic is poorly understood, and specific relationships between experimental and human exposures are not established. Several epidemiologic studies have reported that arsenic exposure in utero increased spontaneous abortion and stillbirth and decreased birth weight (Ihrig et al., 1998; Ahmad et al., 2001; Milton et al., 2005). However, these studies lack detailed information about exact effects of maternal arsenic exposure. The reproductive and developmental toxicity of arsenic have primarily been documented through murine studies, suggesting arsenic as a risk to the developing fetus. In animals, some experimental studies have reported that arsenic intoxication is associated with spermatotoxicity (Waalkes et al., 2003; Pant et al., 2004), inhibition of testicular steroidogenesis and reduction of the weight of the testes and accessory sex organs (Sarker et al., 2003). Arsenic exposure also has been associated with inhibition of ovarian steroidogenesis and gonadotrophins secretion (Chattopadhyay et al., 1999), elevation of adrenocortical steroidogenesis and plasma corticosterone level (Ghosh et al., 1999), as well as with 
severe metabolic disorders such as diabetes in humans (Tseng et al., 2002). However, the actual molecular events resulting in reproductive and developmental toxicity from exposure of arsenic remain unclear.

The purpose of this paper is to review and summarize the major scientific developments on the topic of reproductive and developmental toxicity associated with arsenic exposure, integrating evidence from epidemiological and experimental studies.

\section{ARSENIC EXPOSURE TO HUMAN}

Arsenic is a major global health concern throughout the world widely based on its carcinogenic potential after occupational or environmental exposure (IARC, 1987; NRC, 1999). Arsenic is commonly present in air, water, and soil and could find their routes into the human body through inhalation, ingestion and skin absorption. The primary route of arsenic exposure for the most population is via the ingestion of contaminated food or water. Inhalation or skin absorption of arsenic from contaminated sources is a minor exposure route for the general population (ATSDR 2007). Most ingested and inhaled arsenic is well absorbed through the gastrointestinal tract and lung into the blood stream. Arsenic enters into the human body through these routes, and is distributed in a large number of organs including the lung, liver, spleen, kidney, intestine, skin, and vascular and lymphatic systems, as well as reproductive and nervous systems (Hunter et al., 1942; ATSDR, 2007). After absorption through lung and the gastrointestinal tract, 95 to $99 \%$ of the arsenic is located in erythrocytes, bound to the globin of hemoglobin and is then transported to the other parts of the body. About $70 \%$ of the arsenic is excreted mainly through urine. Most arsenic absorbed into the body is converted by the liver to less toxic methylated form that is efficiently excreted in the urine (WHO, 1981; ATSDR, 1989).

Arsenic is a multi-site carcinogen in humans, causing tumors in a variety of tissues including lung, skin, liver, kidney, and bladder, as well as uterus and prostate (NRC, 1999; Waalkes et al., 2000, 2003). Acute arsenic exposure may cause gastrointestinal tract disorders (Goebl et al., 1990), whereas chronic exposure may exert degenerative, inflammatory, and neoplastic changes of the respiratory, hematopoietic, cardiovascular, and nervous systems (Naiger \& Osweiler, 1989). Although epidemiological data have firmly established arsenic to be a human carcinogen, animal studies are less well defined. Most laboratory animals appear to be substantially less susceptible to arsenic than humans (Naqvi et al., 1994; Huff et al., 2000). It has been reported that chronic oral exposure to inorganic arsenic $(0.05-0.1 \mathrm{mg} / \mathrm{kg} /$ day $)$ causes neurological and hematological toxicity in humans but not in monkeys, dogs, and rats exposed to arsenite or arsenate at doses of 0.72 to 2.8 $\mathrm{mg} / \mathrm{kg} /$ day (Byron et al., 1967).

\section{BIOCHEMICAL METABOLISM OF ARSENICALS}

Exposure of humans to inorganic arsenic results in the urinary excretion of inorganic arsenic and two major methylated metabolites, methyl arsenic and dimethyl arsenic (Crecelius, 1977; Smith et al., 1977; Yamauchi \& Yamamura, 1979). In many organisms, including humans, inorganic arsenic is reduced in the blood from pentavalent arsenate $\left(\mathrm{As}^{5+}\right)$ to trivalent arsenite $\left(\mathrm{As}^{3+}\right)$, then taken up by hepatocytes and oxidatively methylated to monomethyl arsenic acid (MMA) and then to dimethyl arsenic acid (DMA) (Fig. 1) (Aposhian, 1997; Healy et al., 1998; Pott et al., 2001; Thomas et al., 2001). The reduction is facilitated by reductases and the reduced form of glutathione (GSH) along with possibly other thiols as electron donors. Oxidative methylation is carried out by methyltransferases, and S-adenosylme-thionine (SAM) serves as the main methyl donor (Drobna et al., 2005).

Inorganic arsenic in water is abundant in the form of arsenate; it is negatively charged at physiological $\mathrm{pH}$ and slowly taken up by cells (Cohen et al., 2006). Arsenate is 


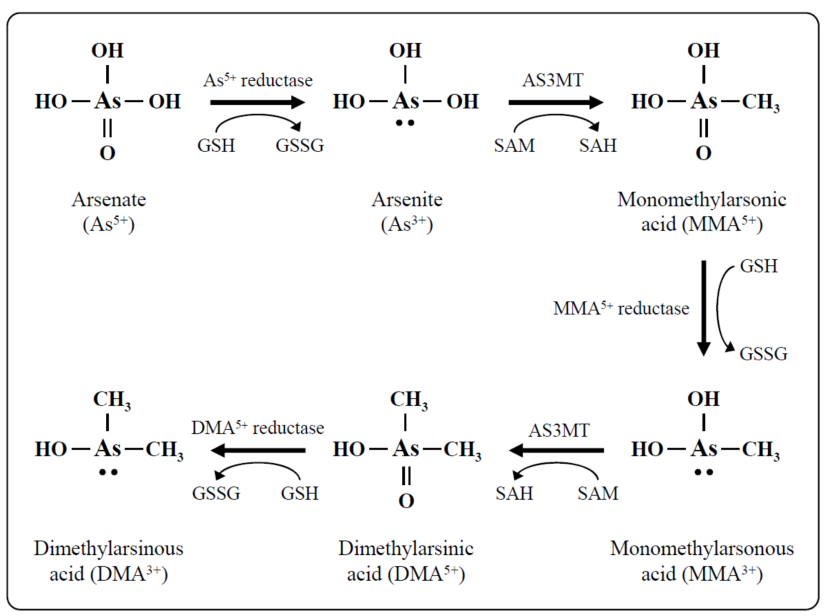

Fig. 1. Metabolic pathway of inorganic arsenic. Arsenate $\left(\mathrm{As}^{5+}\right)$ is reduced by $\mathrm{As}^{5+}$ reductase with glutathione $(\mathrm{GSH})$ to yield arsenite $\left(\mathrm{As}^{3+}\right)$ and glutathione disulfide (GSSG). $\mathrm{As}^{3+}$ is converted to pentavalent monomethylarsonic acid $\left(\mathrm{MMA}^{5+}\right)$, a reaction catalyzed by arsenic-3-methyltransferase (AS3MT), with Sadenosylmethione (SAM) serving as the methyl donor; in the process, SAM is hydrolyzed to Sadenosyl homocysteine (SAH). After the reduction of $\mathrm{MMA}^{5+}$ to $\mathrm{MMA}^{3+}$, a second methylation step result in the synthesis of dimethylarsinic acid $\left(\mathrm{DMA}^{5+}\right)$, and then it is reduced to $\mathrm{DMA}^{3+}$.

rapidly converted to arsenite in vivo (Vahter and Envall, 1983; Vahter \& Marafente, 1985) which is taken up by cells much more quickly than arsenate (Tseng, 2009). Methylation of arsenicals facilitates their excretion from the cell and therefore was long considered a detoxification process, but recent evidence indicates that monomethylated and dimethylated arsenicals have many cyto- and genotoxic effects including increased oxidative stress (Kligerman \& Tennant, 2007), chromosomal aberrations, and oxidative DNA damage (Schwerdtle et al., 2003; Dopp et al., 2004, 2005). Methylated trivalent metabolites are highly reactive and are more potent inhibitors of GSH reductase and thioredoxin reductase compared with arsenite or pentavalent metabolites (Styblo et al., 1997; Lin et al., 1999). Thioredoxin reductases catalyzes the NADPH-dependent reduction of the disulfide bond in oxidized thioredoxin, which is a critical antioxidant enzyme controlling the cellular redox balance (Rossman, 2003).

More importantly, arsenic can pass through the placenta to the developing fetus. In experimental animals, prenatal exposure to inorganic arsenic has resulted in arsenic accumulation in fetuses, including fetal brain (Rodriguez et al., 2002; Miyazaki et al., 2005), and detection of monomethyl and dimethyl arsenicals in fetuses (Hall et al., 2007). In humans, dimethylarsinic acid $\left(\mathrm{DMA}^{5+}\right)$ accounts for nearly $90 \%$ of all detected arsenic in the blood plasma of both the newborns and their mothers (Concha et al., 1998). This form of arsenic accounts for 60 to $70 \%$ of the total detected arsenic in urine of the general population, whereas urine from pregnant women contained more than $90 \%$ arsenic as DMA $^{5+}$. This suggested that arsenic methylation may be increased during pregnancy and that $\mathrm{DMA}^{5+}$ is the major form of arsenic transferred to the fetus.

\section{DEVELOPMENTAL TOXICITY OF ARSENIC}

The elevated evidence now suggests that arsenic exposure in utero also poses health risks to the developing fetus (Vahter, 2009). Various epidemiological studies have found significant associations between prenatal arsenic exposure and adverse infant outcomes, such as infant mortality, low birth weight, and birth defects (Ahmad et al., 2001; Milton et al., 2005; Rahman et al., 2007). These health problems were most evident in individuals exposed to high-level arsenic (IARC, 2004). During pregnancy, high-level exposure to arsenic in drinking water causes pregnancy complications, including fetal loss and premature delivery (Chakraborti et al., 2003), and low-level exposure to arsenic affects uterus and placental growth results in progeny birth weight (Hopenhayn et al., 2003; Rahman et al., 2009). Conclusions from these epidemiological studies are further supported by results from animal models (Ferm and Carpenter, 1968; Hood and Bishop, 1972). Several cross-sectional studies have been reported that woman exposure of chronic arsenic in drinking 
water increases adverse pregnancy outcomes including premature delivery, spontaneous abortion, stillbirth and neonatal death in Bangladesh (Milton et al., 2005), northeastern Taiwan (Yang et al., 2003), and Chile (Hopenhayn-Rich et al., 2000). Despite the strong association between arsenic exposure and a range of child health concerns, the mechanisms by which arsenic elicits these effects remain elusive (Fry et al., 2007; Vahter, 2009; Ahmed et al., 2011).

Arsenic is a well-known teratogen and developmental toxicant in many animal models. Various animal studies have shown that arsenic can produce developmental toxicity, including malformation, growth retardation and fetal death (Tabocova et al., 1996; Golub et al., 1998). Furthermore, developmental toxicity critically depends on dose, route and gestation day following the arsenic exposure (Golub et al., 1998). Fetal malformations were only reported when pregnant rats and mice were intravenous (i.v.) and intraperitoneal (i.p.) injected with inorganic arsenic at early gestation (Stump et al., 1999; DeSesso, 2001). Maternal inhalation or oral ingestion of inorganic arsenic affected fetal development and behavior, but did not cause malformations (Holson et al., 1999; Stump et al., 1999; DeSesso, 2001; Chattopadhyay et al., 2002). The maternal circulation levels of arsenicals are influenced by absorption rates. In oral exposure, arsenic is absorbed into the blood from intestines. It is then transported to the liver and may undergo first-pass metabolism prior to being delivered to the uterus. Intraperitoneal injections, on the other hand, allow arsenic to be taken up by blood vessels directly and may bypass first-pass metabolism (Stump et al., 1999; DeSesso, 2001). In pregnant rats, the maternal blood and embryonic arsenic concentration from i.p. injected mother was significantly higher than those from the orally exposed mother (Hood et al., 1987; Holson et al., 2000a). Inhalation is the least effective means of increasing maternal or embryonic arsenic concentrations, compared to i.p. and i.v. injections and oral exposure (Holson et al., 2000a). Intra- peritoneal injection of $45 \mathrm{mg} / \mathrm{kg}$ sodium arsenate in Swiss mice during gestation day (GD) 8 induced fetal renal and skeletal malformations without affecting maternal weights (Fascineli et al., 2002). However, oral exposure to arsenic did not cause neural tube defects, even at maternally toxic dose levels. Oral gavage with high-dose arsenic trioxide (10 mg/kg/day) in female $\mathrm{Crl}: \mathrm{CD}(\mathrm{SD}) \mathrm{BR}$ rats during GD 14 to 19 decreased fetal weights, but did not induce changes in mating index, fertility index, implantation, or fetal malformation (Holson et al., 2000b). Nevertheless, dimethylarsinic acid $\left(\mathrm{DMA}^{5+}\right)$, an arsenic metabolite, given to pregnant mice and rats by oral gavage caused developmental toxicity (Rogers et al., 1981; Chernoff et al., 1990). CD-1 mice were orally gavaged with $\mathrm{DMA}^{5+}$ at 200 600 $\mathrm{mg} / \mathrm{kg}$ /day during GD 7 to 16 . These mice showed lower maternal weight gain and fetal weight at $200 \mathrm{mg} / \mathrm{kg} / \mathrm{day}$, and a higher incidence of cleft palate at $400 \mathrm{mg} / \mathrm{kg} / \mathrm{day}$. Similarly, during GD 7 to 16 , CD rats were orally gavaged with $\mathrm{DMA}^{5+}$ at 7.5 to $60 \mathrm{mg} / \mathrm{kg} /$ day (Rogers et al., 1981). Maternal weight gain and fetal weight were decreased at $>40 \mathrm{mg} / \mathrm{kg} /$ day. Fetal mortality was increased at 50 or 60 $\mathrm{mg} / \mathrm{kg} /$ day, but no fetal gross malformations were seen in these rats. In a later study, $\mathrm{DMA}^{5+}$ was given to pregnant Sprague-Dawley (SD) rats at $40 \mathrm{mg} / \mathrm{kg}$ /day by oral gavage during GD 6 to 15 . This treatment did not induce maternal weight reduction or maternal lethality, but decreased fetal weight (Chernoff et al., 1990). Furthermore, postnatal developmental changes were observed when arsenic was given in the drinking water to pregnant and lactating rats and continually to the newborns (Rodriguez et al. 2002). Ingestion of drinking water with sodium arsenite $(36.7 \mathrm{mg} / \mathrm{L})$ in SD rats during GD 15 to postnatal day (PND) 16 induced developmental indices including delayed pinna detachement on PND 12 and early eye opening on PND 14 in more litters, compared to the untreated controls (Rodriguez et al. 2002). In physiological development, pinna detachment occurs between PND 3 and 4, and eye opening is observed on 
PND 16. These data indicate that arsenic induces an asynchrony of the maturational processes during postnatal development. Overall, it is assumed that prenatal exposure to arsenic may cause adverse pregnancy outcomes and children's health problem, however, the exact mechanism underlying arsenic-induced developmental toxicity and a direct relationship with reproductive toxicity remains to be elucidated.

\section{REPRODUCTIVE TOXICITY OF ARSENIC}

In males, arsenic may induce gonad dysfunction through declined testosterone synthesis, apoptosis and necrosis (Davila-Esqueda et al., 2012; Shen et al., 2013). However, the male reproductive dysfunction of arsenic exposure on human health is not well established. Recently, few epidemiologic studies have shown that arsenic exposure significantly causes infertility and low sperm quality, as well as erectile dysfunction in men (Nie et al., 2006; Hsieh et al., 2008; Meeker et al., 2010).

Several experimental studies have been demonstrated that significant accumulation of arsenic in testes and accessory sex organs, such as epididymis, seminal vesicle, and prostate gland (Danielsson et al., 1984; Pant et al., 2001). Male mice exposed to sodium arsenite at 20 or $40 \mathrm{mg} / \mathrm{L}$ for 5 weeks in drinking water showed decreased epididymal sperm counts and testicular weight (Chang et al., 2007). Similarly, in male rats, daily exposure to sodium arsenite at $5 \mathrm{mg} / \mathrm{L}$ for 4 weeks in drinking water also resulted in decreased testicular weights, accessory sex organ weights, and epididymal sperm counts, as well as extensive degeneration of a wide variety of germ cells at stage VII of the spematogenic cycle (Jana et al., 2006). Furthermore, arsenic-exposed mice exhibited dose-dependent gradual reductions in seminiferous tubular diameter and various gametogenic cell populations, such as resting spermatocyte, pachytene spermatocyte, and elongated spermatid (Sanghamitra et al., 2008). These results indicated that arsenic exposure may inhibit the spermato- genesis and sperm development.

In addition, arsenic exposure also reduced plasma levels of testosterone and gonadotropin in male mice and rats (Sarkar et al.. 2003; Chinoy et al., 2004; Pant et al.. 2004). Sodium arsenite was given to Wister rat via i.p. injections at 4,5 , or $6 \mathrm{mg} / \mathrm{kg} / \mathrm{day}$ for 26 days. At 5 and $6 \mathrm{mg} / \mathrm{kg} / \mathrm{day}$, relative testicular weight, accessory sex organ weights and epididymal sperm counts were decreased. Moreover, sodium arsenite-treated rats were accompanied by decreases of plasma concentrations of luteinizing hormone ( $\mathrm{LH})$, folliclestimulating hormone (FSH), and testosterone after arsenic exposure. These suggested that arsenic may target on the brain and/or pituitary as well as directly on the germ cells. However, the molecular mechanisms underlying arsenicinduced male reproductive dysfunctions are poorly understood.

There are several possible mechanisms for the antigonadal activities of toxic chemicals. They might exert a direct inhibitory action on the testis, or they might affect the hypothalamic-pituitary axis causing changes in plasma concentrations of LH and FSH. Reduction of plasma $\mathrm{LH}$ might impair Leydig cell function and result in a consequent reduction in testosterone production. Testosterone is a prerequisite for normal spermatogenesis, while $\mathrm{FSH}$ is also required for normal testicular function and spermatogenesis (Fig. 2) (Jana et al., 2006). On the other hand, a possible mechanism for decreased sperm motility might be associated with a direct binding of arsenic to sperm (Uckun et al., 2002). Nuclear chromatins of sperm have large amounts of thiol-rich protamines, and the sperm flagellum is rich in thiols. The thiol groups in sperm nuclear or flagellum provide binding sites for arsenic. Another possible cause of the reduction in serum $\mathrm{LH}, \mathrm{FSH}$, and testosterone levels could be high serum corticosterone levels. High corticosterone can reduce serum gonadotrophins and testosterone levels (Vreeburg et al. 1988; Hardy et al. 2005), and has been reported in sodium arsenite-treated rats (Biswas et al., 1994).

In addition to spermatogenesis, in mice, cholesterol meta- 


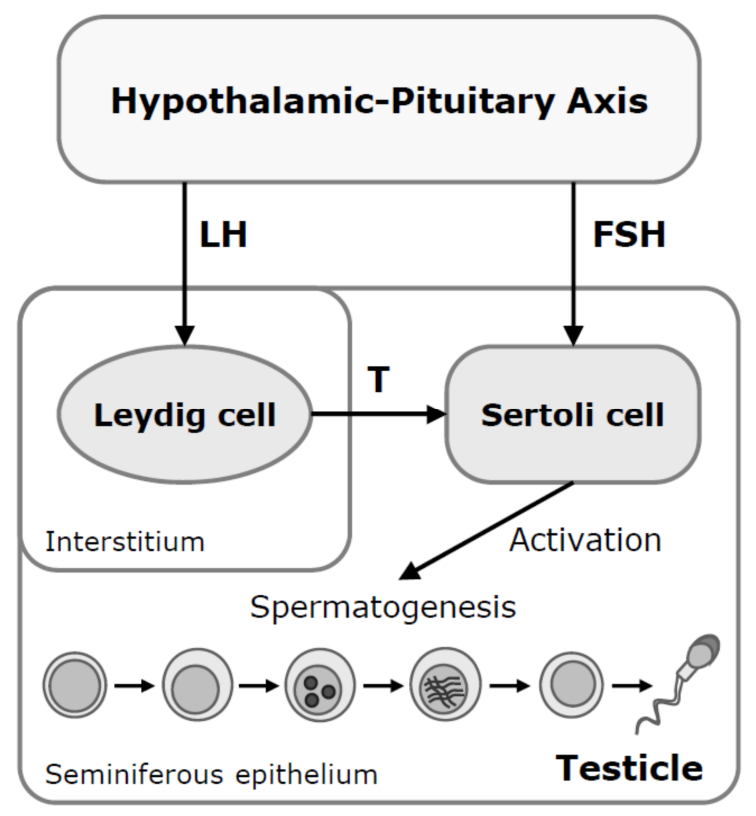

Fig. 2. Hormonal controls of spermatogenesis in the hypothalamic-pituitary-testicular axis. Luteinizing hormone (LH) acts directly upon the Leydig cells to stimulate testosterone ( $\mathrm{T}$ ) production. $\mathrm{T}$ and folliclestimulating hormone (FSH) act upon the Sertoli cells within seminiferous epithelium to support development and maturation of germ cells.

bolism and testosterone production were affected by arsenic exposure (Chinoy et al., 2004). Male mice orally exposed to arsenic trioxide $\left(\mathrm{As}_{2} \mathrm{O}_{3}\right)$ at $0.5 \mathrm{mg} / \mathrm{kg}$ for 30 days showed increased cholesterol levels and decreased expression of $3 \beta$-hydroxysteroid dehydrogenase (HSD) and 17 $\beta$-HSD, two important regulatory enzyme of steroidogenesis. In the testis, cholesterol is a precursor for testosterone synthesis (Kabbaj et al., 2003). 3 $\beta$-HSD mainly converts pregnenolone to progesterone, and 17 $\beta$-HSD converts androstenedione into testosterone. In the seminiferous tubules in the testis, cholesterol in the membrane of developing cells influences the gamete's fertility (Kabbaj et al., 2003). These data suggest that low plasma level of testosterone after arsenic exposure may be due to low enzymatic conversion by the decreases of $3 \beta-H S D$ and $17 \beta-H S D$, rather than a lack of the synthetic precursor cholesterol.

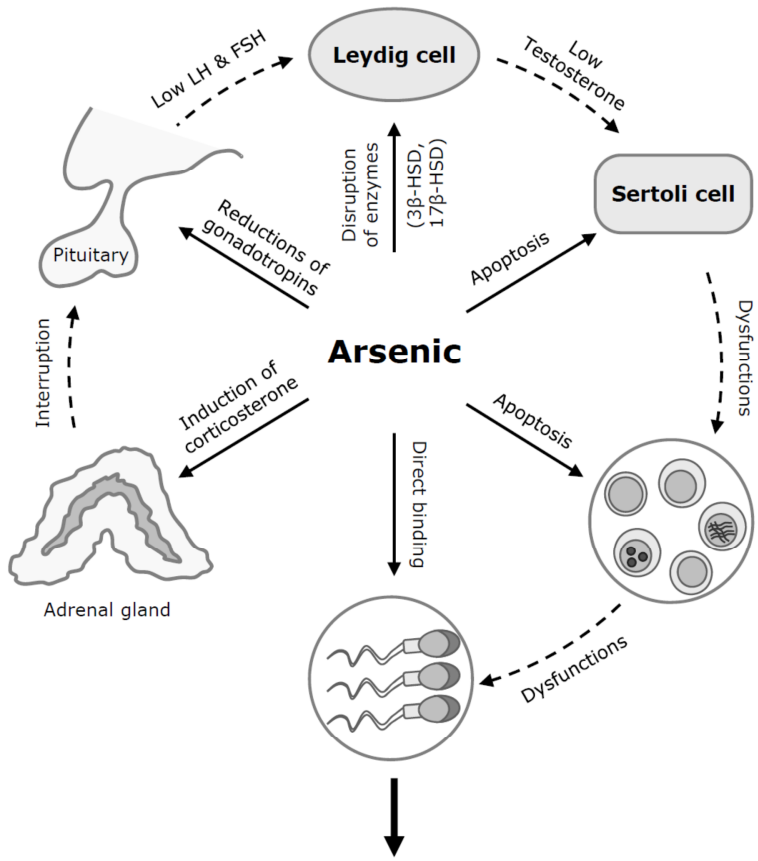

Induction of male reproductive toxicity and infertility

Fig. 3. Possible mechanisms involved in arsenic-induced male reproductive toxicity. Arsenic may inhibit spermatogenesis and sperm maturation following certain key molecular mechanisms including reductions of testosterone and gonadotrophins $\mathrm{LH}$ and FSH, disruptions of steroidogenic enzymes $3 \beta-\mathrm{HSD}$ and $17 \beta$-HSD, negative regulations of $\mathrm{LH}$ and FSH by increased corticosterone, decreases of sperm motility and viability following the direct binding of arsenic (As) to sperm, and direct damages or apoptosis of testicular component germ cells or Sertoli cells. The dotted lines represent negative regulations of the general spermatogenesis following arsenic exposure LH, luteinizing hormone; FSH, follicle-stimulating hormones; $3 \beta$-HSD, $3 \beta$-hydroxysteroid dehydrogenase; $17 \beta$-HSD, $3 \beta$-hydroxysteroid dehydrogenase.

Arsenic exposure may induce cell death or apoptosis in the testicular germ cells or somatic Sertoli cells in vitro (Celino et al., 2009; Kim et al., 2011). In Japanese eel, low-dose $(0.1 \sim 1 \mu \mathrm{M})$ of arsenic inhibits spermatogenesis via steroidogenesis suppression, while high-dose $(100 \mu \mathrm{M})$ of arsenic induces oxidative stress-mediated germ cell 
apoptosis (Celino et al., 2009). We previously showed that arsenic trioxide $\left(\mathrm{As}_{2} \mathrm{O}_{3}\right)$ at $10 \mu \mathrm{M}$ efficiently induces reactive oxygen species (ROS)-related cytotoxicity and apoptotic cell death in mouse TM4 Sertoli cells (Kim et al., 2011). The testicular Sertoli cells interact directly with developing germ cells throughout the process of spermatogenesis. These cells have an indispensable able in the development and movement of germ cells (Russell, 1993; Griswold, 1998). Thus, spermatogenic dysfunction of arsenic toxicity may be associated with direct damages of testicular component cells (Fig. 3).

\section{CONCLUSION}

Arsenic is an important environmental toxicant that affects the reproductive and developmental toxicity. These toxic effects are influenced by the forms, sources, and routes, as well as doses and periods of arsenic exposure. In vivo studies demonstrated that inorganic arsenic, such as sodium arsenite, arsenic trioxide, and dimethyl arsinic acid, an arsenic metabolite, causes reproductive and developmental toxicity. Prenatal exposure to inorganic arsenic by only i.p. or i.v. injection routes causes fetal malformation; in contrast, oral and inhalational exposure to inorganic arsenic affects fetal development, including growth retardation and fetal death. In drinking water, oral exposure to inorganic arsenic causes dysfunctions of spermatogenesis, reductions of testosterone and gonadotrophins, and disruptions of steroidogenesis. However, the reproductive and developmental toxicity of arsenic is poorly understood, and the molecular mechanism of arsenic-induced reproductive toxicity remains unclear. Therefore, we further investigated some of the possible mechanisms that are affected by arsenic causing reproductive toxicity. The crucial mechanisms of arsenic-induced reproductive toxicity may be associated with hormonal regulation and function, binding to sperm, and regulation of steroidogenesis, as well as direct effects of testicular component cells.

\section{ACKNOWLEDGEMENTS}

This study was supported by the Dong-A University Research Fund.

\section{REFERENCES}

Abernathy CO, Thomas DJ, Calderon RL (2003) Health effects and risk assessment of arsenic. J Nutr 133 (suppl 1): $1536 \mathrm{~S}-1538 \mathrm{~S}$.

Ahmad SA, Sayed MH, Barua S, Khan MH, Faruquee MH, Jalil A, Hadi SA, Talukder HK (2001) Arsenic in drinking water and pregnancy outcomes. Environ Health Perspect 109:629-631.

Ahmed S, Mahabbat-e Khoda S, Rekha RS, Gardner RM, Ameer SS, Moore S, Ekstrom EC, Vahter M, Raqib R (2011) Arsenic-associated oxidative stress, inflammation, and immune disruption in human placenta and cord blood. Environ Health Perspect 119:258-264.

Akter KF, Owens G, Davey DE, Naidu R (2005) Arsenic speciation and toxicity in biological systems. Rev Environ Contam Toxicol 184:97-149.

Aposhian HV (1997) Enzymatic methylation of arsenic species and other new approaches to arsenic toxicity. Ann Rev Pharmacol Toxicol 37:397-419.

ATSDR (Agency for Toxic Substances and Disease Registry) (1989) Toxicological Profile for Arsenic. ATSDR/TP88/02. U.S. Department of Health and Human Services. Public Health Service, Atlanta, GA.

ATSDR (Agency for Toxic Substances and Disease Registry) (2007) Toxicological Profile for Arsenic; U.S. Department of Health and Human Services, Public Health Service, Atlanta, GA.

Biswas NM, Roy Chowdhury G, Sarkar M (1994) Effect of sodium arsenite on adrenocortical activities in male rats: Dose-duration dependent responses. Med Sci Res 23:153-154. 
Byron WR, Bierbower GW, Brouwer JB, Hanse WH (1967) Pathological changes in rates and dogs from two year feeding of sodium arsenite or sodium arsenate. Toxicol Appl Pharmacol 10:132-147.

Celino FT, Yamaguchi S, Miura C, Miura T (2009) Arsenic inhibits in vitro spermatogenesis and induces germ cell apoptosis in Japanese eel (Anguilla japonica). Reproduction 138:279-287.

Chakraborti D, Mukherjee SC, Pati S, Sengupta MK, Rahman MM, Chowdhury UK, Lodh D, Chanda CR, Chakraborti AK, Basu GK (2003) Arsenic groundwater contamination in Middle Ganga Plain, Bihar, India: a future danger? Environ Health Perspect 111:1194-1201.

Chang SI, Jin B, Youn P, Park C, Park JD, Ryu DY (2007) Arsenic-induced toxicity and the protective role of ascorbic acid in mouse testis. Toxicol Appl Pharmacol 218:196-203.

Chattopadhyay S, Bhaumik S, Nag Chaudhury A, Das Gupta S (2002) Arsenic induced changes in growth development and apoptosis in neonatal and adult brain cells in vivo and in tissue culture. Toxicol Lett 128:73-84.

Chattopadhyay S, Ghosh S, Chaki S, Debnath J, Ghosh D (1999) Effect of sodium arsenite on plasma levels of gonadotrophins and ovarian steroidogenesis in mature albino rats: duration dependent response. J Toxicol Sci 24:425-431.

Chernoff N, Setzer RW, Miller DB, Rosen MB, Rogers MJ (1990) Effects of chemically induced maternal toxicity on prenatal development in the rat. Teratology 42:651-658.

Chinoy NJ, Tewari K, Jhala DD (2004) Fluoride and/or arsenic toxicity in mice testis with formation of giant cells and subsequent recovery by some antidotes. Fluoride 37:172-184.

Cohen SM, Arnold LL, Eldan M, Lewis AS, Beck BD (2006) Methylated arsenicals: The implications of metabolism and carcinogenicity studies in rodents to human risk assessment. Crit Rev Toxicol 36:99-133.
Concha G, Vogler G, Lezcano D, Nermell B, Vahter M (1998). Exposure to inorganic arsenic metabolites during early human development. Toxicol Sci 44:185-190.

Crecelius EA (1977) Changes in the chemical speciation of arsenic following ingestion by man. Environ Health Perspect 19:147-150.

Cullen WR, Reimer KJ (1989) Arsenic speciation in the environment. Chem Rev 89:713-774.

Danielsson BR, Dencker L, Lindgren A, Tjälve H (1984) Accumulation of toxic metals in male reproduction organs. Arch Toxicol Suppl 7:177-180.

Davila-Esqueda ME, Jimenez-Capdeville ME, Delgado JM, De la Cruz E, Aradillas-Garcia C, Jimenez-Suarez V, Escobedo RF, Llerenas JR (2012) Effects of arsenic exposure during the pre- and postnatal development on the puberty of female offspring. Exp Toxicol Pathol 64, 25-30.

DeSesso JM (2001) Teratogen update: Inorganic arsenic. Teratology 64:170-173.

Dopp E, Hartmann LM, Florea AM, von Recklinghausen U, Pieper R, Shokouhi B, Rettenmeier AW, Hirner AV, Obe G (2004) Uptake of inorganic and organic derivatives of arsenic associated with induced cytotoxic and genotoxic effects in Chinese hamster ovary $(\mathrm{CHO})$ cells. Toxicology and Applied Pharmacology 201:156-165.

Dopp E, Hartmann LM, von Recklinghausen U, Florea AM, Rabieh S, Zimmermann U, Shokouhi B, Yadav S, Hirner AV, Rettenmeier AW (2005) Forced uptake of trivalent and pentavalent methylated and inorganic arsenic and its cyto-/genotoxicity in fibroblasts and hepatoma cells. Toxicological Sciences 87:46-56.

Douer D, Tallman MS (2005) Arsenic trioxide: new clinical experience with an old medication in hematologic malignancies. J Clin Oncol 23:2396-2410.

Drobna Z, Waters SB, Devesa V, Harmon AW, Thomas DJ, Styblo M (2005) Metabolism and toxicity of arsenic in human urothelial cells expressing rat arsenic $(+3$ 
oxidation state)-methyltransferase. Toxicol Appl Pharmacol 207:147-159.

Fascineli ML, Hunter ES 3rd, De Grava Kempinas W (2002) Fetotoxicity caused by the interaction between zinc and arsenic in mice. Teratog Carcinog Mutagen 22:315-327.

Ferm VH, Carpenter SJ (1968) Malformations induced by sodium arsenate. J Reprod Fertil 17:199-201.

Fry RC, Navasumrit P, Valiathan C, Svensson JP, Hogan BJ, Luo M, Bhattacharya S, Kandjanapa K, Soontararuks S, Nookabkaew S, Mahidol C, Ruchirawat M, Samson LD (2007) Activation of inflammation/NF-kappaB signaling in infants born to arsenic-exposed mothers. PLoS Genet 3:e207.

Ghosh D, Chattopadhyay S, Debnath J (1999) Effect of sodium arsenite on adrenocortical activity in immature female rats: Evidence of dose-dependent response. J Environ Sci 11:419-422.

Goebl HH, Schmidt PF, Bohl J, Teltenborn B, Kramer G, Gutman L (1990) Polyneuropathy due to arsenic intoxication: biopsy studies. J Neurol 49:137-149.

Golub MS, Macintosh MS, Baumrind N (1998) Developmental and reproductive toxicity of inorganic arsenic: animal studies and human concerns. J Toxicol Environ Health B Crit Rev 1:199-241.

Griswold MD (1998) The central role of Sertoli cells in spermatogenesis. Semin Cell Dev Biol 9:411-416.

Hall M, Gamble M, Slavkovich V, Liu X, Levy D, Cheng Z, van Geen A, Yunus M, Rahman M, Pilsner JR, Graziano J (2007) Determinants of arsenic metabolism: Blood arsenic metabolites, plasma folate, cobalamin, and homocysteine concentrations in maternal-newborn pairs. Environ Health Perspect 115:1503-1509.

Hardy MP, Gao HB, Dong Q, Ge R, Wang Q, Chai WR, Feng X, Sottas C (2005) Stress hormone and male reproductive function. Cell Tissue Res 322:147-153.

Healy SM, Casarez EA, Ayala-Fierro F, Aposhian HV
(1998) Enzymatic methylation of arsenic compounds. $\mathrm{V}$. Arsenite methyltransferase activity in tissue of mice. Toxicol Appl Pharmacol 148:65-70.

Holson JF, Desesso MJ, Jacobson CF, Farr CH. (2000a) Appropriate use of animal models in the assessment of risk during prenatal development: An illustration using inorganic arsenic. Teratology 62:51-71.

Holson JF, Stump DG, Clevidence KJ, Knapp JF, Farr CH (2000b) Evaluation of the prenatal developmental toxicity of orally administered arsenic trioxide in rats. Food Chem Toxicol 38:459-466.

Holson JF, Stump DG, Ulrich CE, Farr CH (1999) Absence of prenatal developmental toxicity from inhaled arsenic trioxide in rats. Toxicol Sci 51:87-97.

Hood RD, Bishop SL (1972) Teratogenic effects of sodium arsenate in mice. Arch Environ Health 24:62-65.

Hood RD, Vedel-Macrander GC, Zaworotko MJ, Tatum FM, Meeks RG (1987) Distribution, metabolism, and fetal uptake of pentavalent arsenic in pregnant mice following oral or intraperitoneal administration. Teratology $35: 19-25$.

Hopenhayn-Rich C, Browning SR, Hertz-Picciotto I, Ferreccio C, Peralta C, Gibb H (2000) Chronic arsenic exposure and risk of infant mortality in two areas of Chile. Environ Health Perspect 108:667-673.

Hopenhayn C, Ferreccio C, Browning SR, Huang B, Peralta C, Gibb H, Hertz-Picciotto I (2003) Arsenic exposure from drinking water and birth weight. Epidemiology (Cambridge, Mass) 14:593-602.

Hsieh FI, Hwang TS, Hsieh YC, Lo HC, Su CT, Hsu HS, Chiou HY, Chen CJ (2008) Risk of erectile dysfunction induced by arsenic exposure through well water consumption in Taiwan. Environ Health Perspect 116:532536.

Hu J, Shen ZX, Sun GL, Chen SJ, Wang ZY, Chen Z (1999) Long-term survival and prognostic study in acute promyelocytic leukemia treated with all-transretinoic acid, 
chemotherapy, and $\mathrm{As}_{2} \mathrm{O}_{3}$ : an experience of 120 patients at a single institution. Int J Hematol 70:248-260.

Huff J, Chan P, Nyska A (2000) Is the human carcinogen arsenic carcinogenic to laboratory animals. Toxicol Sci $55: 17-23$.

Hunter FT, Kip AF, Irvine W (1942) Radioactive tracer studies on arsenic injected as potassium arsenite. J Pharmacol Exp Ther 76:207-220.

IARC (International Agency for Research on Cancer) (1980) Some metals and metallic compounds. IARC Monogr Eval Carcinog Risk Chem Hum, Lyon, 23: 1-415.

IARC (International Agency for Research on Cancer) (1987) Overall evaluations of carcinogenicity: an updating of IARC Monographs volumes 1 to 42. IARC Monogr Eval Carcinog Risks Hum Suppl, Lyon, 7: 1-440.

IARC (International Agency for Research on Cancer) (2004) Some drinking-water disinfectants and contaminants, including arsenic. IARC Monogr Eval Carcinog Risks Hum, Lyon, 84:1-477.

Ihrig MM, Shalat SL, Baynes C (1998) A hospital-based case-control study of stillbirths and environmental exposure to arsenic using an atmospheric dispersion model linked to a geographical information system. Epidemiology 9:290-294.

Jana K, Jana S, Samanta PK (2006) Effects of chronic exposure to sodium arsenite on hypothalamo-pituitarytesticular activities in adult rats: Possible an estrogenic mode of action. Reprod Biol Endocrinol 16:4-9.

Kabbaj O, Yoon SR, Holm C, Rose J, Vitale ML, Pelletier RM (2003) Relationship of the hormone-sensitive lipasemediated modulation of cholesterol metabolism in individual compartments of the testis to serum pituitary hormone and testosterone concentrations in a seasonal breeder, the mink (Mustela vison). Biol Reprod 68: $722-734$

Kim YJ, Chung JY, Lee SG, Kim JY, Park JE, Kim WR, Joo BS, Han SH, Yoo KS, Yoo YH, Kim JM (2011)
Arsenic trioxide-induced apoptosis in TM4 Sertoli cells: the potential involvement of p21 expression and p53 phosphorylation. Toxicology 285:142-151.

Kligerman $\mathrm{AD}$, Tennant $\mathrm{AH}$ (2007) Insights into the carcinogenic mode of action of arsenic. Toxicology and Applied Pharmacology 222:281-288.

Kosentt MJ (1994) Arsenic. in: Olson KK (Ed.), Poisoning and Drug Overdose. Appleton and Lange, Norwalk, pp87-89.

Lin S, Del Razo LM, Styblo M, Wang CQ, Cullen WR, Thomas DJ (2001) Arsenicals inhibit thioredoxin reductase in cultured rat hepatocytes. Chemical Research in Toxicology 14:305-311.

Liu J, Waalkes MP (2008) Liver is a target of arsenic carcinogenesis. Toxicol Sci 105:24-32.

Mandal BK, Suzuki KT (2002) Arsenic round the world: a review. Talanta 58:201-35.

Meeker JD, Rossano MG, Protas B, Padmanahban V, Diamond MP, Puscheck E, Daly D, Paneth N, Wirth JJ (2010) Environmental exposure to metals and male reproductive hormones: Circulating testosterone is inversely associated with blood molybdenum. Fertil Steril 93: 130-140.

Milton AH, Smith W, Rahman B, Hasan Z, Kulsum U, Dear K, Rakibuddin M, Ali A (2005) Chronic arsenic exposure and adverse pregnancy outcomes in Bangladesh. Epidemiology 16:82-86.

Miyazaki K, Watanabe C, Mori K, Yoshida K, Ohtsuka R (2005) The effects of gestational arsenic exposure and dietary selenium deficiency on selenium and selenoenzymes in maternal and fetal tissues in mice. Toxicology 208: 357-365.

Naiger RD, Osweiler GD (1989) Effect of sub acute lowlevel dietary sodium arsenite on dogs. Fundam Appl Toxicol 13:439-451.

Naqvi SM, Vaishnavi C, Singh H (1994) Toxicity and metabolism of arsenic in vertebrates. In: Nriagu JO 
(ed.), Arsenic in the Environment, Part II: Human Health and Ecosystem Effects. Wiley-Interscience, New York, pp55-91.

Nie JS, Pei QL, Han G, Xu JX, Mu JJ (2006) Semen quality decreased by inorganic arsenic. J Environ Occup Med 23:189-190.

NRC (National Research Council) (1999) Arsenic in Drinking Water. National Academy Press, Washington DC, pp1310.

NRC (National Research Council) (2001) Arsenic in Drinking Water: 2001 Update. National Academy Press, Washington DC, pp1-244.

Pant N, Kumar R, Murthy RC, Srivastava SP (2001) Male reproductive effect of arsenic in mice. Biometals 14:113117.

Pant N, Murthy RC, Srivastava SP (2004) Male reproductive toxicity of sodium arsenite in mice. Hum Exp Toxicol 23:399-403.

Pott WA, Benjamin SA, Yang RS (2001) Pharmacokinetics, metabolism, and carcinogenicity of arsenic. Rev Environ Contam Toxicol 169:165-214.

Rahman A, Vahter M, Ekstrom EC, Rahman M, Golam Mustafa AH, Wahed MA, Yunus M, Persson LA (2007) Association of arsenic exposure during pregnancy with fetal loss and infant death: a cohort study in Bangladesh. Am J Epidemiol 165:1389-1396.

Rahman A, Vahter M, Smith AH, Nermell B, Yunus M, El Arifeen S, Persson L-A, Ekström E-C (2009) Arsenic exposure during pregnancy and size at birth: a prospective cohort study in Bangladesh. Am J Epidemiol 169:304312 .

Rodriguez VM, Carrizales L, Mendoza MS, Fajardo OR, Giordano M (2002) Effects of sodium arsenite exposure on development and behavior in the rat. Neurotoxicol Teratol 24:743-750.

Rogers EH, Chernoff N, Kavlock RJ (1981) The teratogenic potential of cacodylic acid in the rat and mouse. Drug
Chem Toxicol 4:49-61.

Rossman TG (2003) Mechanism of arsenic carcinogenesis: an integrated approach. Mutat Res 533:37-65.

Russell LD (1993) Form, dimensions, and cytology of mammalian Sertoli cells. In: Russell LD, Griswold MD (eds.), The Sertoli Cell. Cache River Press, Clearwater, FL, pp1-37.

Sanghamitra S, Hazra J, Upadhyay SN, Singh RK, Amal RC (2008) Arsenic induced toxicity on testicular tissue of mice. Indian J Physiol Pharmacol 52:84-90.

Sarkar M, Chaudhuri GR, Chattopadhyay A, Biswas NM (2003) Effect of sodium arsenite on spermatogenesis, plasma gonadotrophins and testosterone in rats. Asian J Androl 5:27-31.

Sarkar M, Ray Chaudhuri G, Chattopadhyay A, Biswas NM (2003) Effect of sodium arsenite on spermatogenesis, plasma gonadotrophins and testosterone in rats. Asian $\mathrm{J}$ Androl 1:27-31.

Schwerdtle T, Walter I, Mackiw I, Hartwig A (2003) Induction of oxidative DNA damage by arsenite and its trivalent and pentavalent methylated metabolites in cultured human cells and isolated DNA. Carcinogenesis 24:967-974.

Shen H, Xu W, Zhang J, Chen M, Martin FL, Xia Y, Liu L, Dong S, Zhu YG (2013) Urinary metabolic biomarkers link oxidative stress indicators associated with general arsenic exposure to male infertility in a Han Chinese population. Environ Sci Technol 47:8843-8851

Smith AH, Hopenhayn-Rich C, Bates MN, Goeden HM, Hertz-Picciotto I, Duggan HM, Wood R, Kosnett MJ, Smith MT (1992) Cancer risks from arsenic in drinking water. Environ Health Perspect 97:259-267.

Smith AH, Lopipero PA, Bates MN, Steinmaus CM (2002) Public health. Arsenic epidemiology and drinking water standards. Science 296:2145-2146.

Smith TJ, Crecelius EA, Reading JC (1977) Airborne arsenic exposure and excretion of methylated arsenic compounds. Environ Health Perspect 19:89-93. 
Soignet SL, Maslak P, Wang ZG, Jhanwar S, Calleja E, Dardshti LJ, Corso D, DeBlasio A, Gabrilove J, Scheinberg DA, Pandolfi PP, Warrell Jr RP (1998) Complete remission after treatment of acute promyelocytic leukemia with arsenic trioxide. N Engl J Med 339: 1241-1348.

Stump DG, Holson JF, Fleeman TL, Nemec MD, Farr CH (1999) Comparative effects of single intraperitoneal or oral doses of sodium arsenate or arsenic trioxide during in utero development. Teratology 60:283-291.

Styblo M, Serves SV, Cullen WR, Thomas DJ (1997) Comparative inhibition of yeast glutathione reductase by arsenicals and arsenothiols. Chem Res Toxicol 10:27-33.

Tabocova S, Hunter ES 3rd, Gladen BC (1996) Developmental toxicity of inorganic arsenic in whole embryo: culture oxidation state, dose, time, and gestational age dependence. Toxicol Appl Pharmacol 138:298-307.

Thomas DJ, Styblo M, Lin S (2001) The cellular metabolism and systemic toxicity of arsenic. Toxicol Appl Pharmacol 176:127-144.

Tseng CH (2009) A review on environmental factors regulating arsenic methylation in humans. Toxicology and Applied Pharmacology 235:338-350.

Tseng CH, Tseng CP, Chiou HY, Hsueh YM, Chong CK, Chen CJ (2002) Epidemiologic evidence of diabetogenic effect of arsenic. Toxicol Lett 133:69-76.

Uckun FM, Liu XP, D’Cruz OJ (2002) Human sperm immobilizing activity of aminophenyl arsenic acid and its N-substituted quinazoline, pyrimidine, and purine derivatives: Protective effect of glutathione. Reprod Toxicol 16:57-64.

Uslu R, Sanli UA, Sezgin C, Karabulut B, Terzioglu E, Omay SB, Goker E (2000) Arsenic trioxide-mediated cytotoxicity and apoptosis in prostate and ovarian carcinoma cell lines. Clin Cancer Res 6:4957-4964.

Vahter M (2009) Effects of arsenic on maternal and fetal health. Annu Rev Nutr 29:381-399.
Vahter M, Envall J (1983) In vivo reduction of arsenate in mice and rabbits. Environ Res 32:14- 24.

Vahter M, Marafente E (1985) Reduction and binding of arsenate in marmoset monkeys. Archives of Toxicology 57:119-124.

Vreeburg JT, Samaun K, Verkade HJ, Verhoef P, Ooms MP, Weber RF (1988) Effects of corticosterone on the negative feedback action of testosterone, 5 alphadihydrotestosterone and estradiol in the adult male rat. J Steroid Biochem 29:93-98.

Waalkes MP, Keefer LK, Diwan BA (2000) Induction of proliferate lesions of the uterus, testes, and liver in Swiss mice given repeated injections of sodium arsenate: possible estrogenic mode of action. Toxicol Appl Pharmacol 166:24-35.

Waalkes MP, Ward JM, Liu J, Diwan BA (2003) Transplacental carcinogenicity of inorganic arsenic in the drinking water: induction of hepatic, ovarian, pulmonary, and adrenal tumors in mice. Toxicol Appl Pharmacol 186:7-17.

Wasserman GA, Liu X, Parvez F, Ahsan H, Factor-Litvak P, van Geen A, Slavkovich V, LoIacono NJ, Cheng Z, Hussain I, Momotag H, Graziano JH (2004) Water arsenic exposure and children's intellectual function in Araihazar, Bangladesh. Environ Health Perspect 112: 1329-1333.

Watanabe C, Inaoka T, Matsui T, Ishigaki K, Murayama N, Ohtsuka R (2003) Effects of arsenic on younger generations. J Environ Sci Health 38(Part A):129-139.

WHO (World Health Organization (1981) Environmental Health Criteria 18: Arsenic. WHO, Geneva.

WHO (World Health Organization) (2000) Air Quality Guidelines for Europe, 2nd ed. WHO Regional Publications, European Series, Copenhagen, 91:1-288.

WHO (World Health Organization) (2001) Arsenic and Arsenic Compounds (Environmental Health Criteria 224), 2nd ed. WHO International Programme on Chemical Safety, 
Geneva.

Yamauchi H, Yamamura Y (1979) Dynamic changes of inorganic and methylarsenic compounds in human urine after oral intake of arsenic trioxide. Indust Hygiene $17: 79-83$.

Yang CY, Chang CC, Tsai SS, Chuang HY, Ho CK, Wu TN (2003) Arsenic in drinking water and adverse pre- gnancy outcome in an arseniasis-endemic area in northeastern Taiwan. Environ Res 91:29-34.

Zhang TC, Cao EH, Li JF, Ma W, Qin JF (1999) Induction of apoptosis and inhibition of human gastric cancer MGC-803 cell growth by arsenic trioxide. Eur J Cancer 35:1258-1263. 